第 Springer

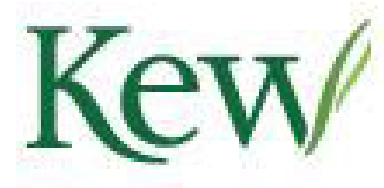

PLANTS PEOPLE

POSSIBILITIES

\title{
Saxifraga lingulata and S. lantoscana
}

\section{Author(s): T. A. Sprague}

Source: Bulletin of Miscellaneous Information (Royal Botanic Gardens, Kew), Vol. 1911, No. 3 (1911), pp. 129-133

Published by: Springer on behalf of Royal Botanic Gardens, Kew

Stable URL: http://www.jstor.org/stable/4114981

Accessed: 24-06-2016 16:47 UTC

Your use of the JSTOR archive indicates your acceptance of the Terms \& Conditions of Use, available at

http://about.jstor.org/terms

JSTOR is a not-for-profit service that helps scholars, researchers, and students discover, use, and build upon a wide range of content in a trusted digital archive. We use information technology and tools to increase productivity and facilitate new forms of scholarship. For more information about JSTOR, please contact support@jstor.org.

Springer, Royal Botanic Gardens, Kew are collaborating with JSTOR to digitize, preserve and extend access to Bulletin of Miscellaneous Information (Royal Botanic Gardens, Kew) 


\title{
ROYAL BOTANIC GARDENS, KEW.
}

\author{
B U L L E T I N
}

of

\section{MISCELLANEOUS INFORMATION.}

No. 3.]

$[1911$.

\section{XII.-SAXIFRAGA LINGULATA AND S. LANTOSCANA.}

\section{T. A. Sprague.}

Recent correspondence in the Gardeners' Chronicle (ser. 3, vol. xlviii. pp. 311 , 340, 371, 416, 426, 454, 474, Oct. 29-Dec. 24, 1910) has shown that some horticulturists claim specific status for Sarifraga lantoscana, while others prefer to treat it as a variety of S. lingulata. Apart from this difference of opinion, some confusion has arisen as to matters of fact, and it seems desirable, therefore, to give an historical account of the matter.

As the question whether a given group should be regarded as a variety or a distinct species depends partly on the definitions assigned to these terms, it may be well to state that the writer is in entire accordance with the views elaborated by Briquet in the preface to the third volume of Burnat's Flore des Alpes Maritimes. As numerous intermediate forms (apart from possible hybrids) undoubtedly exist between S. lingulata and S. lantoscana, the latter is here regarded as a variety of $S$. lingulata.

It is obvious that no classification of S. lingulata and S. lantoscana can be considered satisfactory which is not based on the study of all the varieties of $S$. lingulata, and it will therefore be necessary also to take into consideration S. australis, Moric. The species S. cochlearis, Reichb., S. catalaunica, Boiss. et Reut., and S. crustata, Vest., have been considered varieties of $S$. lingulata, but they are now generally accorded suparate rank, and their history need not be traced.

Saxifraga lingulata was described in 1792 by Bellardi, Appendix ad Floram Pedemontanam, p. 20, from specimens collected in the Pesio valley, the mountains of Limone and elsewhere in Piedmont. As Bellardi's work appears to be scarce, his diagnosis may be reproduced :-

"Saxifraga lingulata. Saxifraga foliis radicatis longissimis linearibus sulcatis cartilagineis integerrimis, caule folioso paniculato. Frequens in alpibus maritimis locis rupestribus, praecipue in valle

(19061-6a.) Wt 118-9. 1125, 4/11, D \& S. 

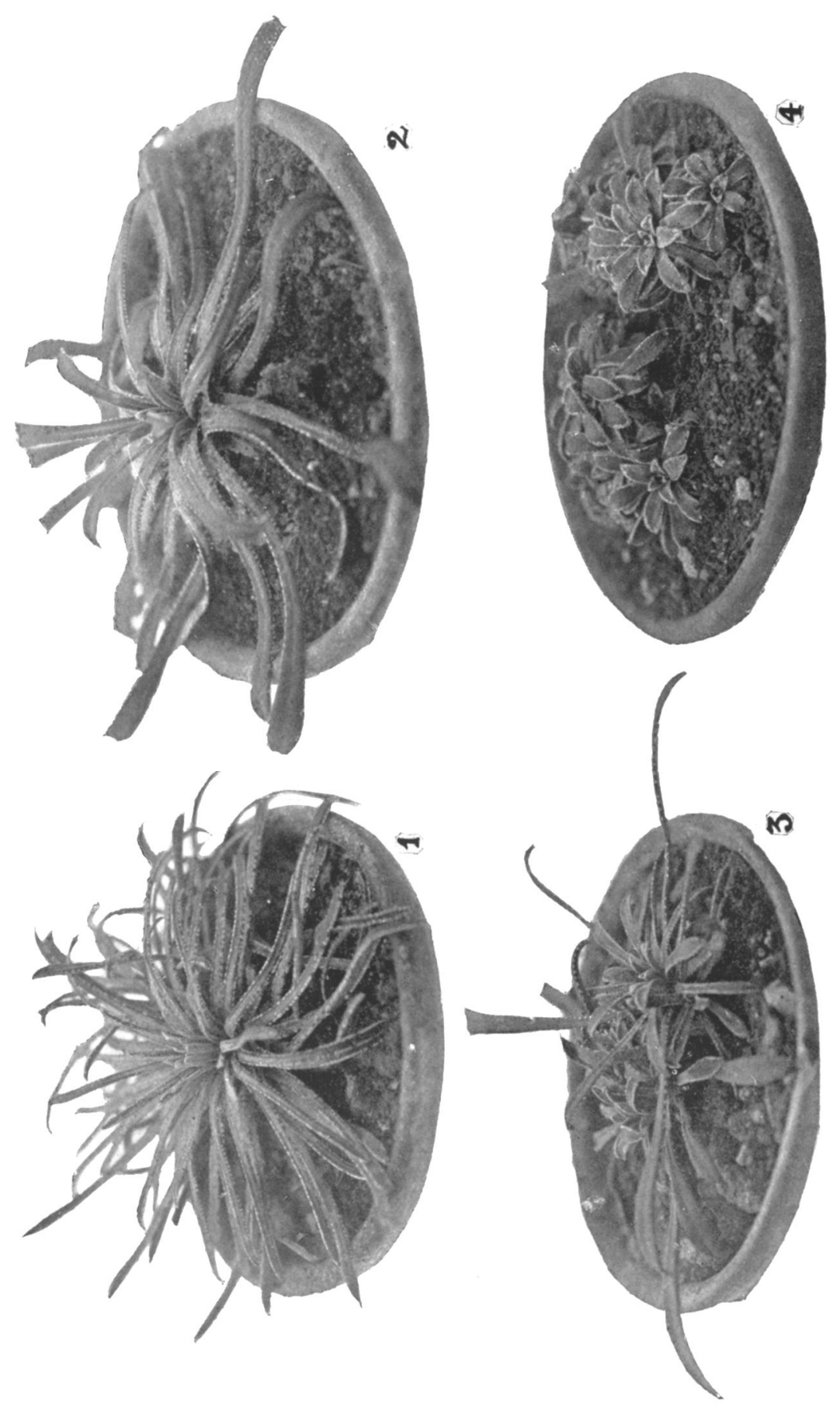

To face page 129.] 
Pisii, in montibus Limoni, aliisque locis alpinis Monregalensibus. . . . Pro nova et distincta species colitur in hortis Londinensibus, referente cl. Smithio, cui plura specimina misi."

Specimens of $S$. lingulata collected by Bellardi in Piedmont were distributed in James Dickson's Collection of Dried Plants, fasc. 3, 1791, No. 63, accompanied by a printed ticket as follows :-

"Saxifraga callosa, Smith, Obs. Bot. ined. Foliis radicalibus aggregatis lineari-lingulatis margine cartilagineo-tuberculatis, caule paniculato. Sm. - Piedmont, Dr. Bellardi, August."

Smith's name thus antedates Bellardi's by a year, but it has never been accepted by other botanists. In Rees's Cyclopaedia, vol. xxxi. 1819, under Saxifraga, No. 2, Smith retained the name S. callosa, however, and quoted as a synonym s'. longifolia, Lapeyr., from which A. P. De Candolle had carefully distinguished it four years previously.

S. lingulata, Bellardi, did not obtain recognition as a distinct species until thirteen years had elapsed after its publication. Lamarck and De Candolle in 1805 quoted it as a synonym of S. longifolia, Lapeyr. (Fl. Franç. ed. 3, vol. iv, p. 359) ; and Sternberg in 1810 referred it to $S$. longifolia, var. a (Rev. Saxifr. p. 1). In 1815, however, De Candolle recognised it as a distinct species (Fl. Franç. ed. 3, vol. vi. p. 516); and in 1819 Bertoloni gave a long and careful description of it in his Flora Alpium Apuanarum (Amoen. Ital. p. 358).

Saxifruga australis was described in 1820 by Moricand, Flora Veneta, p. 431, from material collected on Mt. Virgine near Naples by Gussone, who sent it to Moricand under the name S. Aizoon. Moricand's diagnosis is as follows :-

"Saxifraga australis, noh. S. foliis radicalibus rosulatis lanceolatis margine incrustatis basi ciliatis; caulinis ovatis subdenticulatis acutis; caule glabro anguloso, panicula ramosa multiflora; calycibus glabris, petalis ovatis obtusis calyce triplo longioribus."

In 1830 Seringe in DC. Prodr. vol. iv. p. 20 gave an amended description of S. australis, as follows :-

"S. australis (Moric! fl. ven. i. p. 431) glaberrima, caule anguloso, foliis rosularum oblongo-spathulatis margine crustaceis basi ciliatis, caulinis oblongis subdenticulatis acutiusculis, panicula ramosa multiflora, petalis ovatis obtusis calyce multo longioribus, stylis per anthesin rectis adscendentibus. l'lanta rhizocarpica. In monte Virgine prope Neapolim. . . . Nullo modo differt ex Moretti a S. longifolia (v. s. in herb. Moricand). Speciei character non satis notus."

In 1823 Moretti, Tent. Saxifr. p. 5, had reduced S. australis, Moric., doubtfully to S. lingulata; and this reduction was confirmed by Gussone, Fl. Sic. Prodr. vol. i. 1827, p. 482 ; Tenore, Fl. Nap. vol. iv. 1830, pp. 59, 191 ; Sternberg, Rev. Saxifr. Suppl. 2, 1831, p. 53 ; Bertoloni, Fl. Ital. vol. iv. 1839 , p. 456 ; and Moris, Fl. Sard. vol. ii. $1840-1843$, p. 146, t. 74 . Tenore, l.c. 59 (Syll. Fl. Nap. p. 200) also reduced S. thyrsoidea, Tausch in Syll. Ratisb. vol. ii. 1828, p. 240, to S. lingulata, var. australis. This reduction, however, escaped the notice of subsequent botanists, and $S$. thyrsoidea was lost sight of. Engler did not account for it in his monograph of Saxifraga, and it appeared as an independent species in the Index Kewensis. 
Gussone in 1842 restored specific rank to S. australis, having in the meantime seen specimens of typical $S$. lingulata from the Col di Tenda (Florae Siculae Synopsis, vol. i. p. 466). Subsequent writers on Sicilian botany, including Strobl in Flnra, 1887, p. 164, and Lojacono, Flora Sicula, vol. i. part 2, p. 209, also kept up S. australis ; whereas Engler, Monogr. d. Gattung Saxifraga, 1872, p. 237, Nyman, Consp. Fl. Eur. p. 267, and Fiori and Paoletti, Fl. Anal. Ital. vol. i. 1898 , p. 538, who dealt with a wider area, treated it as a variety of $S$. lingulata.

Saxifraga lantoscana, Boiss. et Reut., was discovered by the authors in the Lantosque valley, Alpes Maritimes, and was described in Boissier, Diagn. Pl. Nov. ser. 2, No. 2, 1856, p. 63, from flowering specimens cultivated in Boissier's garden at Valleyres.

Ardoino, Fl. Alp.-Mar. 1867, p. 149, and Rouy, Suites Fl. Fr. vol. ii. p. 61, retained S. lantoscana as a distinct species. Engler, Monogr. d. Gattung Saxifraga, 1872, p. 237, reduced it to a variety of S. lingulata; and this reduction has been accepted by Nyman, Consp. Fl. Eur. 1882, p. 267 ; Arcangeli, Comp. Fl. Ital. 1882, p. 255 ; Ball in Trans. Linn. Soc. ser. 2, vol. v. 1896, p. 160 ; Fiori and Paoletti, Fl. Anal. Ital. vol. i. 1898, p. 538 ; Rouy and Camus, Fl. de France, vol. vii. 1901, p. 79 ; Burnat, Fl. Alpes Marit. vol. iii. 1902, p. 260 ; and Coste, Fl. de France vol. ii. 1903, p. 138.

From the foregoing account it will have been gathered that there is a large preponderance of opinion in favour of including $S$. australis and $S$. lantoscana under $S$. lingulata. As might be expected, the narrower conception of $S$. lingulata appears to be confined to botanists who have been dealing with relatively small areas, while the wider conception is generally adopted by the writers of larger floras. The strongest evidence, however, in favour of treating S. lantoscana as a variety of $S$. lingulata is given by the writer of a local flora. Burnat, Flore des Alpes Maritimes, vol. iii. p. 260, divides $S$. lingulata into two varieties : a. Bellardii, Sternb., which is typical S. lingulata, Bellardi ; and $\beta$. lantoscana, Engl. In addition to the localities quoted for these varieties Burnat gives under $S$. lingulata a long list of localities which he is unable to refer with certainty to either variety. He discusses the varieties as follows :-

"Boissier et Reuter (l.c.) ont caractérisé comme suit la var. $\beta$ : 'Affinis S. lingulatae, Bell., vallis finitimae Tendensis incolae, ab ea differt virore minus griseo ad brunneum magis vergenti, foliis supra saepius convexis nec ut in $S$. lingulata sulcatis, foliis inferne multo minus longe attenuatis raroque et obsoleteque acutatis, crusta marginali tenuiori et ob paginae superioris convexitatem minus perspicua.' M. Engler (l.c.) s'est borné a la diagnose suivante : 'Folia brevia, inferne minus longe attenuata, apice non attenuata, crusta marginali tenuiori.' On sépare facilement les échantillons typiques de cette variété dont les feuilles subspatulées ou cunéiformes vers leur base ont environ 30 à $40 \mathrm{~mm}$. long., parfois moins, sur 5 à $7 \mathrm{~mm}$., parfois $8 \mathrm{~mm}$. de larg., avec un sommet obtus, plus ou moins arrondi, rarement acutiuscule, tandis que les échantillons de la var. $\boldsymbol{a}$ ont des feuilles plus longues (jusqu'à $11 \mathrm{~cm}$.), 
moins larges, plus insensiblement élargies de la base au sommet qui est acutiuscule ou aigu. Mais entre ces formes extrêmes se recontrent de très nombreux intermédiaires douteux. Concernant la couleur du feuillage et la marge foliaire crustacée blanche, simulant des dentelures, nous ne trouvons nulle différence à noter. Sur les echantillons d'herbier il en est de même des caractères tirés de la disposition de la surface des feuilles. L'espèce varie du reste beaucoup: certains échantillons atteignent 50 et même $60 \mathrm{~cm}$. de haut. avec une panicule de 30 à $35 \mathrm{~cm}$. de long. sur 15 à $20 \mathrm{~cm}$. de larg., tandis que certaines colonies montrent des tiges de 10 à $15 \mathrm{~cm}$. avec une panicule étroite, de 5 à $6 \mathrm{~cm}$. long.; les pétales varient dans leur forme et longueur (jusqu'a $13 \mathrm{~mm}$., parfois seulement $7 \mathrm{~mm}$.) arec ou sans taches purpurines à leur base."

Examination of the material in the Kew herbarium confirms the result arrived at by Burnat and other authorities, that it is best to treat $S$. lantoscana and $S$. australis as varieties of $S$. lingulata. Owing to the large number of intermediate forms it is difficult to divide S. lingulata (in the broad sense) into varieties, and it is quite probable that different results might be arrived at from the study of different herbaria. As a basis for future work, however, it may he well to state the conclusions arrived at from the study of the Kew material, which includes a fine series of specimens forming part of the Churchill herbarium, which was bequeathed to Kew in 1906 (see Kew Bull. 1906, p. 387).

Four more or less distinct races may be recognized. The first (fig. 1) is typical S. lingulata, Bellardi (var. Bellardii, Sternberg). This is characterized by numerous long linear acute leaves, channelled on the upper surface, with a conspicuous calcareuus incrustation. It appears to be all but confined to the Italian part of the Alpes Maritimes, and I have seen no specimens except from the neighbourhood of the Col di Tenda. It is represented in the Kew herbarium by a co-type, collected by Bellardi and distributed in Dickson's Collection of Dried Plants, No. 63, as S. callos $a$, Smith.

The second race corresponds to S. australis, Moric. (S. lingulata, var. australis, Engl.). It appears to vary considerably in the shape and size of the leaves according to situation, and is accordingly difficult to define. Well-grown plants from lower altitudes (fig. 2) have long broadly linear or linear-spathulate leaves, nearly flat on the upper surface. Specimens from higher altitudes have short broadly spathulate leaves, resembling those of lantoscana, but broader. The distribution of S. australis is as follows, according to the Kew material :- Mountains of Carrara and Massa, Pistojan Apennines, Monte Majella and Monte Morrone in Abruzzo, mountains near Latronico in Basilicata, and the mountains of Northern Sicily. It is probably this race of $S$. lingulata which has been discovered recently in Calabria (Longo in Ann. di Bot. Roma, vol. i. 1903, p. 98).

There are no Sardinian specimens of S. lingulata in the Kew herbarium but the figure given by Moris, Fl. Sard. t. 74, suggests that the Sardinian plant belongs to S. australis. This is the view taken by Nyman, Consp. Fl. Eur. p. 267, who gives the distribution of S. australis as Southern Italy, Sicily and Sardinia. 
The third race (fig. 3), to which in the meantime it does not appear desirable to give a name, is represented by specimens gathered near the Col di Tenda, by Mr. Reginald Farrer, on the Aiguille de Menton by Hawker, and the Cime d'Anan, near Fontan, by Reverchon. It is characterised by elongated spathulate obtuse leaves with a fairly conspicuous incrustation.

The fourth race (fig. 4) is S. lantoscana, Boiss. et Reut. (S. lingulata, var. lantoscana, Ingl.). It is distinguished by short spathulate very obtuse leaves, more or less convex on the upper surface, with a less conspicuous but more continuous incrustation. It occurs in the French departments of Hautes Alpes, Basses Alpes, Var and Alpes Maritimes, and it is probably this race which is quoted under typical S. lingulata from Bouches-du-Rhone by Rouy and Camus. From the localities given for typical $S$. lingulata by Rouy and Camus it is probable that their 'lingulata' comes under S. lantoscana as here understood. S'. lantoscana is represented in the Kew herbarium by a co-type, a specimen cultivated at Valleyres and communicated by Reuter to the late Mr. G. C. Churchill.

As some doubt has been cast on the idenitity of the plant cultivated at Kew and elsewhere in this country under the name S. lingulata var. lantoscana, it may be well to state that it appears to be correctly named. It is hoped that it may be possible to give more detailed descriptions of the races of $S$. lingulata when the living plants in the Kew collection come into flower. Kew is indebted for plants of $S$. lingulata (type and varieties) to Miss Willmott, Mr. Reginald Farrer, and Messrs. Heath and Sons, Cheltenham.

\section{Explanation of Plates.}

1. Saxifraga lingulata, Bellardi (typical).-Plant received from Miss Willmott in 1910.

2. S. lingulata, var. australis, Engl.-Plant received from Miss Willmott in 1910.

3. S. lingulata, var.-Plant received from Mr. R. Farrer in 1910, collected on rocks by the Col di Tenda.

4. S. lingulata, var. lantoscana, Engl.--Kew plant.

Figures slightly reduced from natural size.

\section{XIII.-DIAGNOSES AFRICANAE: XL.}

1211. Loranthus (Rufescentes) nitidulus, Sprague in Dyer, Fl. 'Trop. $\Lambda$ fr. vol. vi. sect. 1 , p. 283 , anglice [Loranthaceae-Eulorantheae]; affinis $L$. discolori, Engl., a quo foliis angustioribus supra nitidulis conspicue reticulatis differt.

Ramuli juniores pilis multiramosis ferrugineo-pubescentes, mox glabri. Folia anguste lanceolato-oblonga, apice obtusa, basi obtusa vel rotundata, $3 \cdot 3-5 \cdot 7 \mathrm{~cm}$. longa, $1 \cdot 2-1 \cdot 7 \mathrm{~cm}$. lata, coriacea, supra glabra, nitidula, subtus ferrugineo-tomentosa ; petioli $1-1 \cdot 4 \mathrm{~cm}$. longi. Umbellae 4-florae, ferrugineo-pubescentes ; pedunculus $2.5 \mathrm{~mm}$. longus; pedicelli $1 \cdot 5-2 \mathrm{~mm}$. longi ; bractea ovato-oblonga, $2 \mathrm{~mm}$. longa, 